\title{
ANALISIS SURVIVAL MENGGUNAKAN REGRESI WEIBULL PADA LAJU KESEMBUHAN PASIEN TUBERKULOSIS PARU DI RSUD ALOEI SABOE KOTA GORONTALO
}

\author{
Isran K. Hasan ${ }^{1 *}$, Winni A. Pakaya ${ }^{2}$, Novianita Achmad ${ }^{3}$, Dewi Rahmawaty Isa ${ }^{4}$ \\ 1,2,3,4 Jurusan Matematika, Universitas Negeri Gorontalo, Bone Bolango 96119, Indonesia \\ *Penulis Korespondensi.Email: isran.hasan@ung.ac.id
}

\begin{abstract}
Abstrak
Penelitian ini membahas mengenai analisis survival pada pasien Tuberkulosis Paru di RSUD ALoei Saboe menggunakan Regresi Weibull untuk mengetahui faktor-faktor yang mempengaruhi laju kesembuhan pasien. Untuk menganalisis waktu survival digunakan kurva Kaplan-Meier kemudian dilanjutkan menggunakan Uji Log Rank untuk melihat perbedaan antar kelompok dalam satu kurva. Regresi Weibull digunakan untuk mengetahui faktor-faktor yang signifikan berdasarkan uji $\log$ rank terhadap laju kesembuhan pasien Tuberkulosis Paru. Hasil penelitian memberikan kesimpulan bahwa umur, sesak nafas, demam, batuk, riwayat penyakit dan kebiasaan merokok merupakan faktor yang berpengaruh secara signifikan terhadap laju kesembuhan pasien Tuberkulosis Paru.
\end{abstract}

Kata Kunci: Analisis Survival; Regresi Weibull; Tuberkulosis; Kaplan Meier; Log Rank

\begin{abstract}
This study was aimed at discussing survival analysis in Pulmonary Tuberculosis patients in Aloei Saboe using Weibull regression to find out the factors that influence the patient's recovery rate. To analyze the survival time, the Kaplan-Meier curve is used then the process continues into Log-Rank Test to see the differences between groups in a curve. Weibull Regression is used to determine the significant factors based on a log-rank test in the rate of recovery of Pulmonary Tuberculosis patients. The results of the study concluded age, shortness of breath, fever, cough, history of illness and smoking habits are factors that significantly influence the rate of recovery of Pulmonary Tuberculosis patients.

Keywords: Survival Analysis; Weibull Regression; Pulmonary Tuberculosis; Kaplan Meier; Log Rank
\end{abstract}

\section{Pendahuluan}

Penyakit Tuberkulosis Paru adalah penyakit yang disebabkan oleh Mycobakterium Tuberculosis dan bersifat menular. Tuberkulosis Paru di Indonesia masih menjadi masalah penyebab kematian ketiga di dunia. World Health Organization setiap tahunnya mulai mempublikasikan tentang Global Tuberkulosis Report sejak tahun 1997. Tercatat dalam Global Tuberkulosis Report yang dirilis pada 17 Oktober 2019 bahwa Indonesia adalah negara tertinggi ketiga setelah China dan India dengan jumlah pengidap penyakit Tuberkulosis Paru sebanyak 268 juta [1]. Sementara itu berdasarkan angka penemuan kasus menurut Provinsi pada Profil Kesehatan Indonesia tahun 2018, Provinsi Gorontalo berada di peingkat 6 dengan persentase 70,8 \%. Pada tahun 2019 sendiri meningkat menjadi 73,6\% program Tuberkulosis Paru Dinas Kesehatan Provinsi Gorontalo [2]. Dari data tidak terdapat informasi mengenai laju kesembuhan Tuberkulosis Paru dan faktor -faktor yang mempengaruhinya. Oleh karena itu, diperlukan suatu analisis statistik mengenai masalah tersebut.

Salah satu metode statistika yang sering digunakan dalam menganalisis laju kesembuhan adalah Analisis survival. Analisis survival adalah kumpulan prosedur statistik untuk analisis data dengan hasil variabel yang diperhatikan yaitu waktu. Beberapa kegunaan analisis survival yang pertama 
adalah memperkirakan probabilitas survival suatu kejadian menurut waktu. Kedua, menyimpulkan status kesehatan penduduk. Ketiga, membandingkan survival suatu kejadian antar kelompok. Keempat, mengidentifikasi laju suatu kejadian yang dialami penduduk dalam periode waktu tertentu [3]. Data yang diperoleh merupakan data pengamatan terhadap individu yang diamati dan waktu terjadinya kejadian dari setiap individu, data ini kemudian dilakukan pengambilan sampel menggunakan pengamatan tersensor dan pengamatan tidak tersensor [4].

Dalam analisis survival terdapat dua fungsi utama yaitu fungsi hazard dan fungsi survival. Fungsi hazard adalah laju kegagalan dari suatu peristiwa yang dimaksud, yaitu saat individu mengalami suatu kejadian dalam interval waktu t dengan syarat ia telah bertahan sampai waktu tersebut. Fungsi survival merupakan probabilitas survival sampai waktu tertentu yang dapa diestimasi menggunakan metode parametrik [5]. Metode parametrik dapat menjelaskan tentang individu dalam kelompok, waktu survival, serta peubah-peubah yang mempengaruhinya atau dapat menjelaskan variabel-variabel yang mempengaruhi individu dalam kelompok terhadap waktu survival-nya. Salah satu metode parametrik yang sering digunakan adalah Regresi Weibull karena distribusi Weibull memiliki sifat yang lebih fleksibel jika dibanding dengan model lain. Hal ini karena distribusi Weibull memiliki parameter shape $\beta$ yang membuat kurva hazard lebih fleksibel [6].

Beberapa penelitian menggunakan analisis survival diberbagai kasus seperti analisis survival pada kasus finasial [7][8], termasuk pada kasus COVID-19 [9][10]. Disamping itu, terdapat penelitian yang menggunakan analisis survival dengan melibatkan Regresi Weibull seperti yang dilakukan oleh Solehah dan Fatekurohman [6] serta Lukitasari, dkk [11] dan Baghestani, dkk [12]. Adapun penelitian mengenai pasien Tuberkulosis Paru telah dilakukan oleh Kazempour-Dizaji, dkk [13] yang menggunakan cumulative incidence function (CIF) dalam menganalisis laju kematian pasien Tuberkulosis Paru. Penelitian mengenai Tuberkulosis Paru juga dilakukan oleh Daniel, dkk [14] yang menggunakan distribus gompertz yang dibandingkan dengan model cox proportional hazard dengan kesimpulan bahwa model dengan gompertz memiliki AIC yang terendah. Pembahasan terkait Tuberkulosis Paru juga dilakukan oleh Rajak, dkk [15] dengan melibatkan metode conditional autoregresive.

Berdasarkan uraian diatas maka penelitian ini akan berfokus pada penggunaan Regresi Weibull meskipun telah ada penelitian sebelumnya mengenai Regresi Weibull. Namun, penelitian tersebut menggunakan Regresi Weibull pada pasien kanker paru-paru yang memiliki perbedaan variabel dan perilaku dengan pasien Tuberkulosis Paru yang menjadi objek pada penelitian ini. Selain itu, penelitian sebelumnya mengenai analisis survival pada Tuberkulosis Paru berfokus pada laju kematian dan tidak menggunakan Regresi Weibull sebagai metode analisisnya. Oleh karena itu, peneliti ingin menggunakan model Regresi Weibull dalam menganalisis laju kesembuhan pasien Tuberkulosis Paru di RSUD. Aloei Saboe Kota Gorontalo untuk mengetahui peluang survival pasien tuberkulosis paru berdasarkan analisis kurva Kaplan Meier dan Faktor-faktor apa yang berpengaruh secara signifikan terhadap laju kesembuhan pasien Tuberkulosis.

\section{Metode Penelitian}

Data yang digunakan pada penelitian ini adalah data sekunder yaitu data rekam medis RSUD. Prof. Dr. Hi. Aloei Saboe dari bulan September 2019 sampai bulan Desember 2019. Adapun langkahlangkah analisis data yang dilakukan dalam penelitian ini yaitu :

1. Membuat karakteristik pasien Tuberkulosis Paru dari waktu survival dan variabel independen.

2. Membuat serta menganalisis kurva Kaplan Meier berdasarkan variabel independen dan melakukan uji $\log$ Rank.

3. Melakukan uji distribusi Weibull pada data menggunakan statistik uji Anderson-Darling. Jika data tidak berdistribusi Weibull maka dapat dilakukan transformasi terhadap data dengan memerhatikan bentuk kurva distribusi data tersebut.

4. Mendeteksi apabila terjadinya multikolineritas pada variabel independen. Jika data terdeteksi adanya multikolinearitas maka dapat ditangani menggunakan Analisis Komponen Utama. Jika asumsi multikolinearitas sudah teratasi maka dapat dilanjutkan dengan pemelihan model terbaik menggunakan kriteria AIC. 
5. Melakukan seleksi model terbaik dengan kriteria pada AIC.

6. Melakukan uji signifikansi parameter secara parsial dan serentak.

7. Melakukan subtitusi pada model Regresi Weibull ke dalam fungsi hazard.

8. Menghitung nilai hazard ratio dari variabel independen yang berpengaruh terhadap model untuk mengetahui laju kesembuhan pada pasien Tuberkulosis Paru.

\section{Hasil dan Pembahasan1}

\subsection{Statistika Deskriptif}

Untuk memberikan gambaran terhadap karakteristik data terkait dengan faktor-faktor yang diduga mempengaruhi laju kesembuhan pasien Tuberkulosis Paru maka digunakan statistika deskriptif. Faktor-faktor yang diduga mempengaruhi Tuberkulosis Paru diantaranya yaitu umur, jenis kelamin, sesak napas, demam, batuk, riwayat penyakit Tuberkulosis Paru sebelumnya, pekerjaan dan kebiasaan merokok. Berikut adalah deskriptif data dari waktu survival dan umur yang ditunjukkan dalam Tabel 1.

Tabel 1. Statistika Deskriptif

\begin{tabular}{lcccc}
\hline Variabel & Mean & Variance & Min & Max \\
\hline Time & 6,75 & 13,032 & 1,00 & 17,00 \\
Usia & 49,22 & 451,297 & 3,00 & 89,00 \\
\hline
\end{tabular}

Pada Tabel 1 dapat diketahui bahwa rata-rata lama pasien rawat inap (waktu survival) penderita Tuberkulosis Paru adalah 7 hari dan variansnya sebesar 13,032. Pada jumlah hari rawat inap yang paling sedikit sebanyak 1 hari dan yang paling lama yaitu 17 hari. Selain itu, dapat diketahui bahwa rata-rata umur pasien Tuberkulosis Paru yaitu 49 tahun dan variansnya 451,297. Sedangkan umur pasien yang paling muda berusia 3 tahun dan untuk pasien paling tua berusia 89 tahun atau dapat dikatakan yang muda yaitu anak-anak hingga yang tertua merupakan lansia.

Analisis statistika deskriptif pada data kategorik yakni status tersensor sebanyak sebanyak 21 pasien dengan status tersensor dan 44 pasien dengan status tidak tersensor. Pada variabel jenis kelamin sebanyak 24 pasien dengan jenis kelamin perempuan dan 44 pasien dengan jenis kelamin laki-laki. Pada variabel sesak nafas sebanyak 38 pasien disertai sesak nafas dan 27 pasien tidak disertai sesak nafas. Pada variabel batuk sebanyak pasien 43 yang disertai batuk dan 22 pasien tidak disertai batuk. Pada variabel demam sebanyak pasien 33 yang disertai demam dan 32 pasien tidak disertai demam. Pada variabel riwayat penyakit sebanyak pasien 33 yang memiliki riwayat penyakit dan 32 pasien memiliki riwayat penyakit. Pada variabel pekerjaan sebanyak pasien 38 yang memiliki pekerjaan dan 27 pasien tidak bekerja. Pada variabel kebiasaan merokok sebanyak pasien 56 yang tidak memiliki kebiasaan merokok dan 9 pasien memiliki kebiasaan merokok.

\subsection{Analisis Kurva Kaplan-Meier dan Uji Log Rank}

Kurva survival Kaplan Meier digunakan untuk mendeskripsikan karakteristik waktu survival pasien Tuberkulosis Paru berdasarkan faktor-faktor yang diduga mempengaruhinya. Sedangkan uji Log Rank digunakan untuk mengetahui apakah terdapat perbedaan antar kurva survival antara kelompok yang berbeda.

Kurva probabilitas waktu survival pada variabel Time (waktu survival) yang dapat dapat diinterpretasikan kedalam plot kumulatif survival yang ditampilkan pada Gambar 1. 


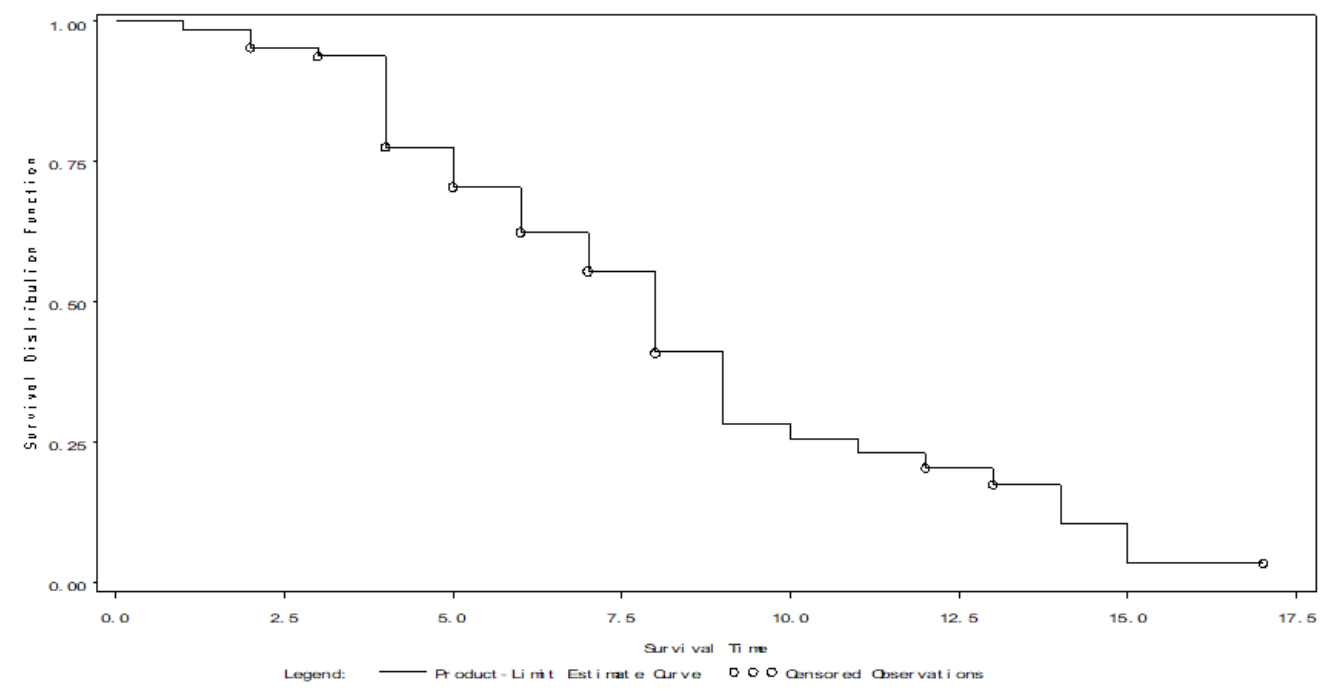

Gambar 1. Kurva Survival Data Waktu Survival

Berdasarkan Gambar 1, dapat diketahui bahwa kurva survival tersebut menginformasikan secara visual bahwa semakin besar waktu survival (T), maka probabilitas survival $S(t)$ akan semakin kecil. Hal ini menunjukan bahwa semakin lama pasien Tuberkulosis Paru mengalami kesembuhan pada waktu $(t)$ maka probabilitas seseorang pasien Tuberkulosis Paru untuk tidak sembuh hingga waktu $t$ semakin kecil mendekati nol.

Selanjutnya akan dilakukan analisis mengenai karakteristik waktu survival pasien Tuberkulosis Paru di Rumah Sakit Aloei Saboe berdasarkan faktor-faktor yang diduga mempengaruhinya. Untuk faktor-faktor yang diduga mempengaruhi laju kesembuhan pasien Tuberkulosis Paru adalah sebagai berikut: Umur, Jenis Kelamin, Sesak Nafas, Batuk, Demam, Riwayat penyakit Tuberkulosis Paru, Pekerjaan dan Kebiasaan Merokok.

\subsubsection{Faktor Jenis Kelamin}

Faktor jenis kelamin merupakan salah satu faktor yang diduga memengaruhi laju kesembuhan pasien Tuberkulosis Paru yang terdiri dari pasien laki-laki dan pasien perempuan. Kurva survival Kaplan-Meier berdasarkan jenis kelamin dapat ditunjukkan dalam Gambar 2.



Gambar 2. Kurva Survival Faktor Jenis Kelamin 
Garis hitam menunjukkan kurva survival pasien berjenis kelamin perempuan, sedangkan garis merah untuk pasien berjenis kelamin laki-laki. Dari visualisasi kurva pada Gambar 2, terlihat bahwa kurva survival pasien berjenis kelamin laki-laki lebih sering berada diatas kurva survival pasien berjenis kelamin perempuan. Dapat disimpulkan bahwa probabilitas untuk tidak mengalami perbaikan kondisi klinis pasien laki-laki lebih besar dari pada probabilitas pasien yang berjenis kelamin perempuan. Dilanjutkan dengan uji Log Rank dan didapat bahwa nilai Log Rank yaitu 0,0242 . Jika dibandingkan dengan nilai $X_{0,05 ; 1}^{2}=3,841$, maka kesimpulannya gagal tolak $\mathrm{H}_{0}$ atau dapat dikatakan bahwa tidak terdapat perbedaan yang signifikan antara waktu kesembuhan pasien Tuberkulosis Paru dengan jenis kelamin laki-laki maupun dengan pasien jenis kelamin perempuan.

\subsubsection{Faktor Sesak Napas}

Faktor sesak nafas merupakan salah satu faktor yang diduga memengaruhi laju kesembuhan pasien Tuberkulosis paru yang terdiri dari pasien yang disertai dengan sesak napas dan tidak sesak napas. Kurva survival Kaplan-Meier berdasarkan terdapat tidaknya sesak napas ditunjukkan seperti Gambar 3.

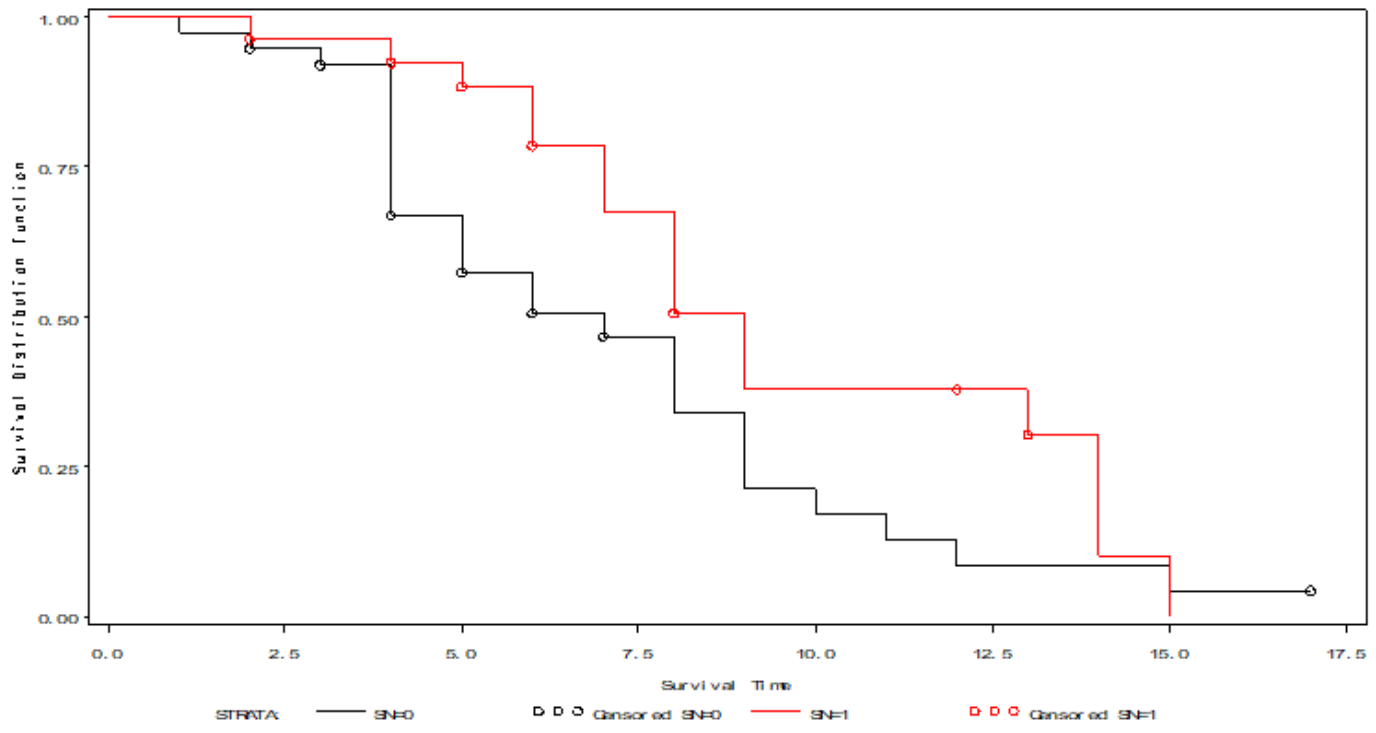

Gambar 3. Kurva Survival Faktor Sesak Napas

Garis hitam menunjukkan kurva survival pasien yang sesak nafas, sedangkan garis merah untuk pasien yang tidak sesak nafas. Dari visualisasi kurva pada Gambar 3, terlihat bahwa kurva survival pasien tidak sesak lebih sering berada diatas kurva survival pasien yang sesak nafas. Dapat disimpulkan bahwa probabilitas untuk tidak mengalami perbaikan kondisi klinis pasien yang tidak sesak nafas lebih besar dari pada probabilitas pasien yang sesak. Dilanjutkan dengan uji Log Rank dan didapat bahwa nilai $\log \operatorname{Rank}$ yaitu 3,5744. Jika dibandingkan dengan nilai $X^{2}{ }_{0,05 ; 1}=3,841$, maka kesimpulannya gagal tolak $\mathrm{H}_{0}$ atau dapat dikatakan bahwa tidak terdapat perbedaan yang signifikan antara waktu kesembuhan pasien Tuberkulosis Paru dengan jenis kelamin laki-laki maupun dengan pasien jenis kelamin perempuan.

\subsubsection{Faktor Batuk}

Faktor batuk merupakan salah satu faktor yang diduga memengaruhi laju kesembuhan pasien Tuberkulosis Paru yang terdiri dari pasien yang disertai dengan batuk dan pasien yang tidak disertai batuk. kurva survival Kaplan-Meier berdasarkan pasien yang disertai batuk dan tidak ditunjukkan pada Gambar 4. 


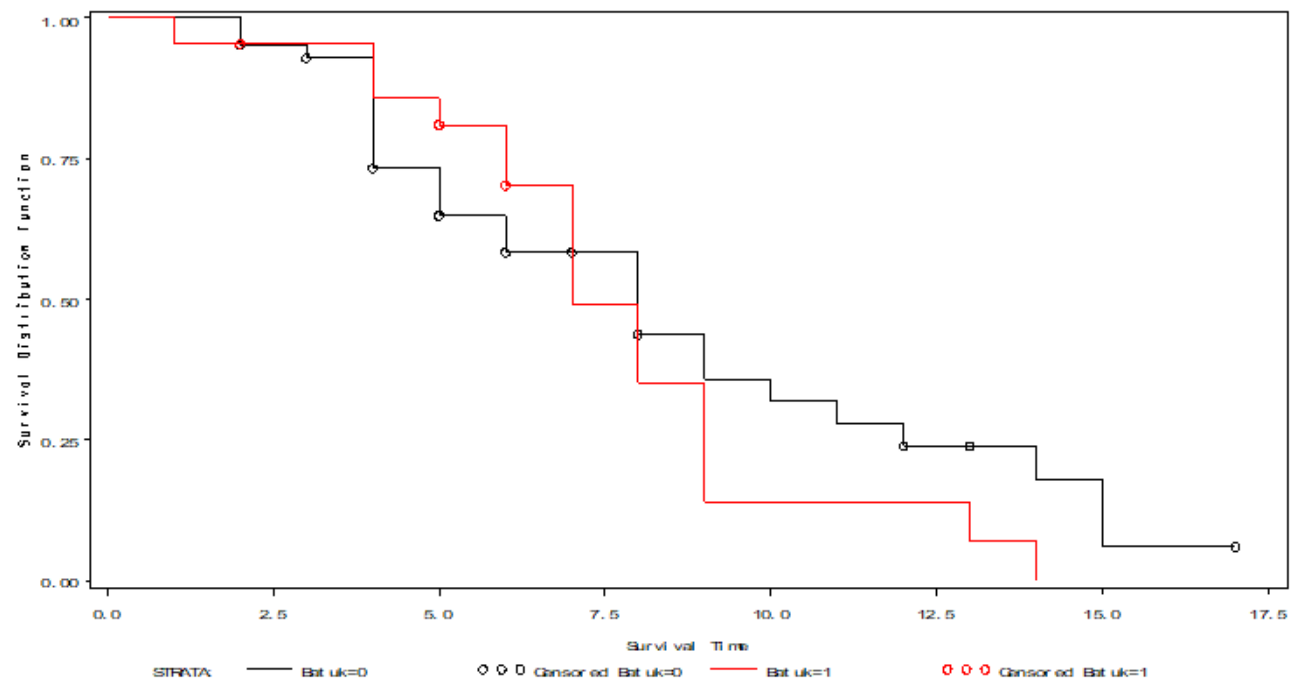

Gambar 4. Kurva Survival Faktor Batuk

Garis hitam menunjukkan kurva survival pasien disertai dengan batuk, sedangkan garis merah untuk pasien yang tidak disertai batuk. Dari visualisasi kurva pada Gambar 4, terlihat bahwa kurva pasien yang batuk lebih sering berada diatas kurva pasien yang tidak disertai batuk. Jadi dapat disimpulkan bahwa probabilitas tidak mengalami perbaikan kondisi klinis pasien yang disertai dengan batuk lebih besar daripada pasien yang tidak batuk. Dilanjutkan dengan uji Log Rank dan didapat bahwa nilai uji $\log \operatorname{Rank}$ sebesar 0,5484. Jika dibandingkan dengan nilai $X^{2}{ }_{0,05 ; 1}=3,841$, maka kesimpulannya gagal tolak $\mathrm{H}_{0}$ atau dapat dikatakan bahwa tidak terdapat perbedaan yang signifikan antara kurva survival pasien yang disertai batuk dengan kurva survival pasien yang tidak disertai dengan batuk.

\subsubsection{Faktor Demam}

Faktor demam merupakan salah satu faktor yang diduga memengaruhi laju kesembuhan pasien Tuberkulosis Paru yang terdiri dari pasien yang disertai dengan demam dan tidak. Kurva survival Kaplan-Meier berdasarkan pasien yang disertai demam dan tidak disertai demam ditunjukkan pada Gambar 5.

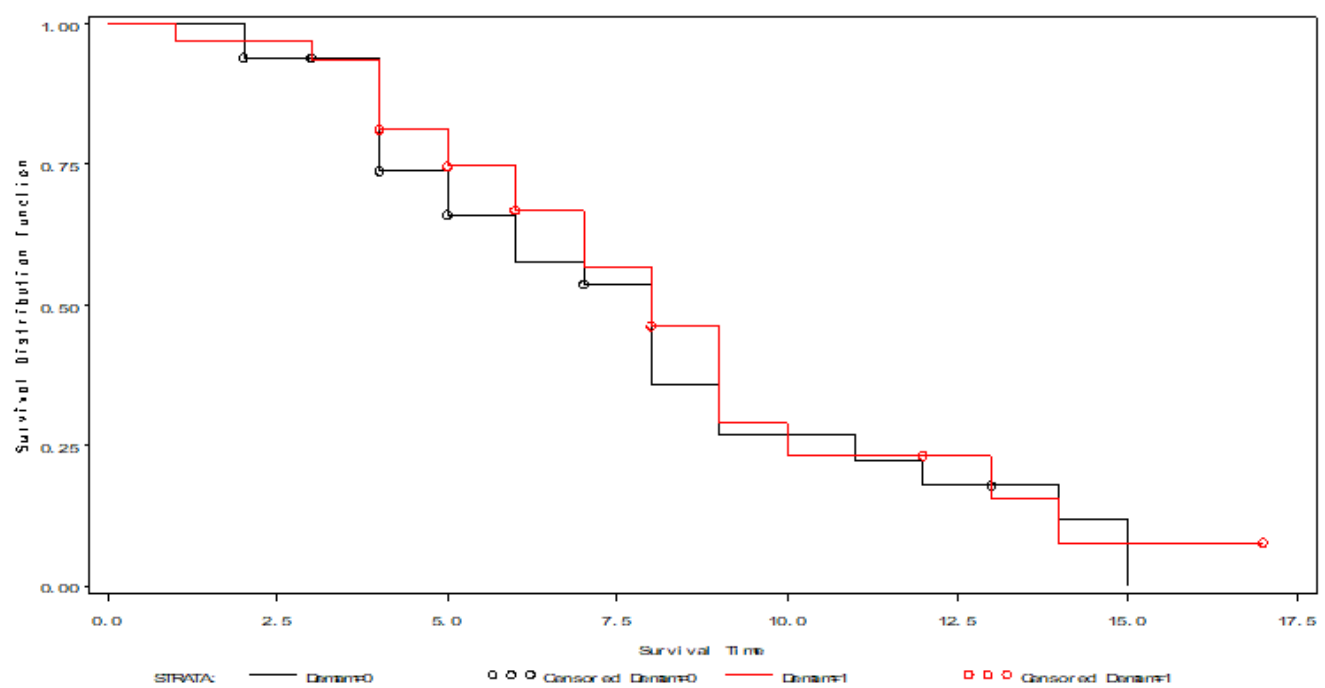

Gambar 5. Kurva Survival Faktor Demam

Garis merah menunjukkan kurva survival pasien tidak disertai dengan demam, sedangkan garis hitam untuk pasien yang disertai demam. Dari visualisasi kurva pada Gambar 5, terlihat bahwa kurva 
pasien yang disertai dengan demam lebih sering berada diatas kurva pasien yang tidak disertai dengan demam bahkan saling berimpit. Jadi dapat disimpulkan bahwa pasien yang tidak disertai demam memiliki probabilitas tidak sembuh lebih besar daripada pasien yang disertai demam. Dilanjutkan dengan uji Log Rank dan didapat bahwa nilai uji Log Rank sebesar 0,2780 Jika dibandingkan dengan nilai $X_{0,05 ; 1}^{2}=3,841$, maka kesimpulannya gagal tolak $\mathrm{H}_{0}$ atau dapat dikatakan bahwa tidak terdapat perbedaan yang signifikan antara kurva survival pasien yang disertai demam dengan kurva survival pasien yang tidak disertai dengan demam.

\subsubsection{Faktor Riwayat Penyakit Tuberkulosis Paru}

Faktor memiliki riwayat Tuberkulosis Paru merupakan salah satu faktor yang diduga memengaruhi laju kesembuhan pasien Tuberkulosis Paru yang terdiri dari pasien yang disertai dengan riwayat penyakit Tuberkulosis Paru dan tidak memiliki riwayat penyakit Tuberkulosis Paru. Kurva survival Kaplan-Meier berdasarkan terdapat tidaknya riwayat Tuberkulosis Paru dapat ditunjukkan pada Gambar 6.

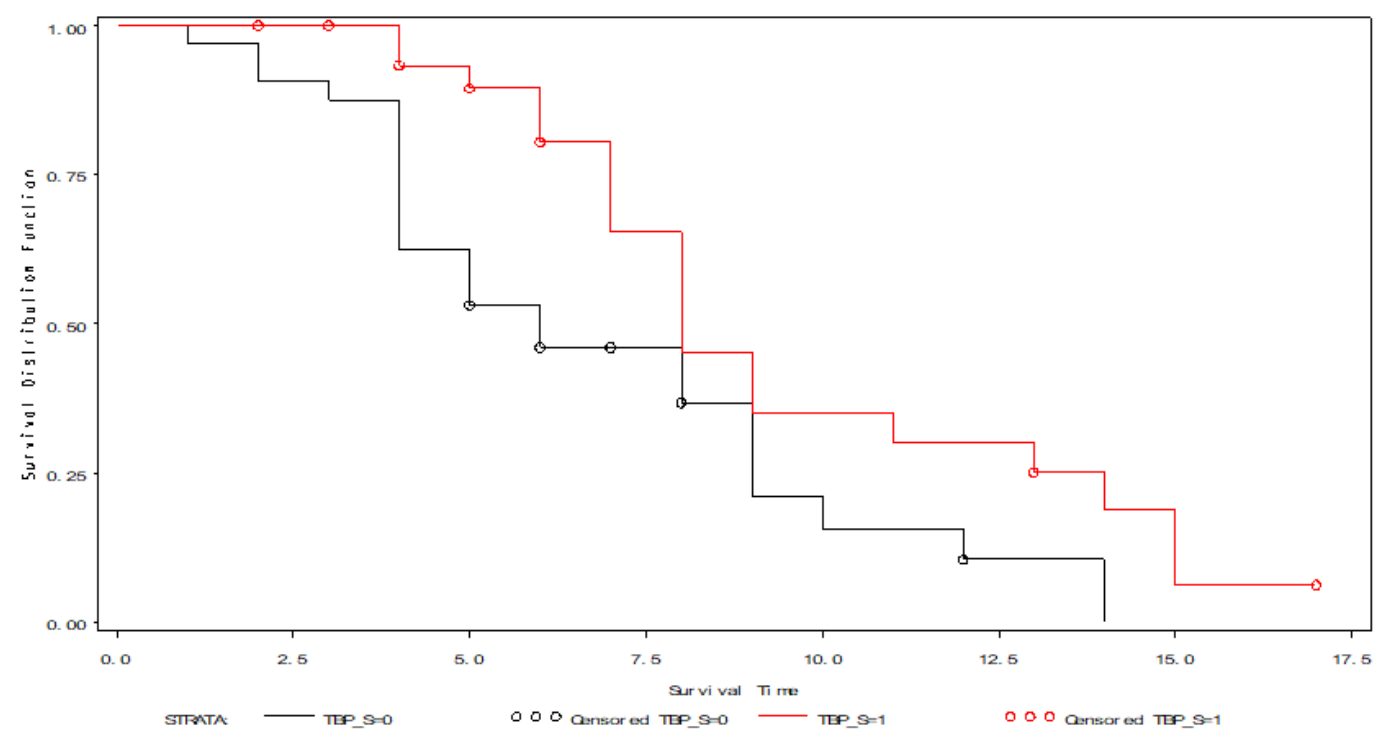

Gambar 6. Kurva Survival Faktor Riwayat Penyakit Tuberkulosis Paru

Garis merah menunjukkan kurva survival pasien tidak disertai dengan riwayat penyakit Tuberkulosis Paru, sedangkan garis hitam untuk pasien yang disertai riwayat Tuberkulosis Paru. Dari visualisasi kurva pada Gambar 6, terlihat bahwa kurva survival pasien yang disertai dengan riwayat Tuberkulosis sering berada dibawah dari kurva pasien yang tidak memiliki riwayat penyakit Tuberkulosis sehingga dapat disimpulkan bahwa probabilitas tidak mengalami kondisi klinis lebih baik pada pasien yang tidak memiliki riwayat penyakit Tuberkulosis lebih tinggi daripada pasien yang memiliki riwayat penyakit Tuberkulosis. Dilanjutkan dengan uji Log Rank dan didapat bahwa nilai uji $\log$ Rank sebesar 5,8918 Jika dibandingkan dengan nilai $X_{0,05 ; 1}^{2}=3,841$, maka kesimpulannya tolak $\mathrm{H}_{0}$ atau dapat dikatakan bahwa terdapat perbedaan yang signifikan antara kurva survival pasien yang disertai dengan riwayat Tuberkulosis Paru dengan kurva survival pasien yang tidak disertai dengan riwayat Tuberkulosis Paru.

\subsubsection{Faktor Pekerjaan}

Faktor pekerjaan merupakan salah satu faktor yang diduga memengaruhi laju kesembuhan pasien Tuberkulosis Paru yang terdiri dari pasien bekerja dan tidak bekerja. Kurva survival KaplanMeier berdasarkan pekerjaan pasien Tuberkulosis Paru ditunjukkan pada gambar 7 . 


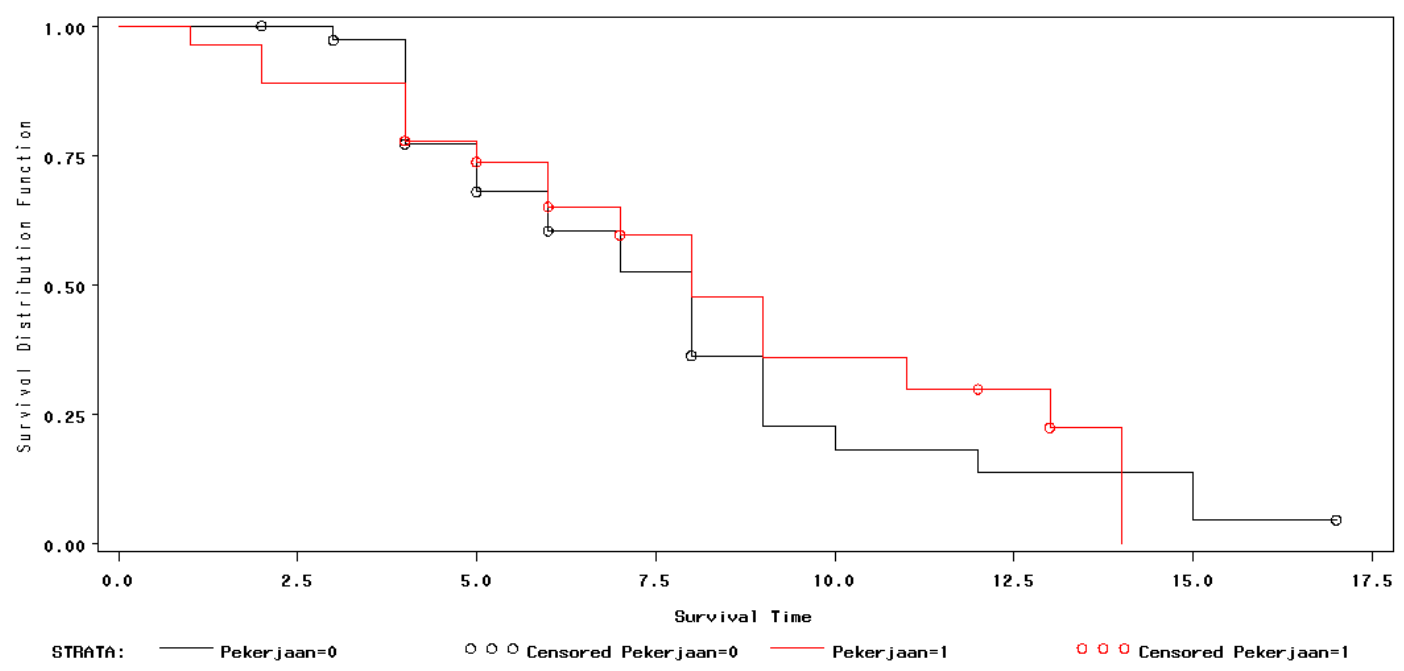

Gambar 7. Kurva Survival Faktor Pekerjaan

Garis merah menunjukkan kurva survival pasien tidak bekerja, sedangkan garis hitam untuk pasien yang bekerja. Dari visualisasi kurva pada Gambar 7, terlihat bahwa kurva pasien yang tidak bekerja lebih sering berada diatas kurva pasien yang bekerja. Jadi dapat disimpulkan bahwa probabilitas tidak sembuh pasien yang tidak bekerja lebih besar dari pada probabilitas pasien yang bekerja. Dilanjutkan dengan uji Log Rank dan didapat bahwa nilai uji Log Rank sebesar 0,1014 Jika dibandingkan dengan nilai $X_{0,05 ; 1}^{2}=3,841$, maka kesimpulannya gagal tolak $\mathrm{H}_{0}$ atau dapat dikatakan bahwa tidak terdapat perbedaan yang signifikan antara kurva survival pasien yang bekerja dengan kurva survival pasien yang tidak bekerja.

\subsubsection{Faktor Kebiasaan Merokok}

Faktor Kebiasaan merokok merupakan salah satu faktor yang diduga memengaruhi laju kesembuhan pasien Tuberkulosis Paru yang terdiri dari pasien tidak merokok dan merokok. Kurva survival Kaplan-Meier berdasarkan kebiasaan merokok pasien Tuberkulosis Paru ditunjukkan pada Gambar 8.



Gambar 8. Kurva Survival Faktor Kebiasaan Merokok

Garis merah menunjukkan kurva survival pasien tidak merokok, sedangkan garis hitam untuk pasien yang merokok. Dari visualisasi kurva pada Gambar 8, terlihat bahwa kurva pasien yang tidak 
merokok kadang berada diatas maupun berada di bawah kurva pasien yang merokok. Jadi dapat disimpulkan bahwa probabilitas pasien yang merokok maupun tidak merokok mengalami perbaikan kondisi klinis yang sama. Dilanjutkan dengan uji Log Rank dan didapat bahwa nilai uji Log Rank sebesar 0,0570 Jika dibandingkan dengan nilai $X_{0,05 ; 1}^{2}=3,841$, maka kesimpulannya gagal tolak $\mathrm{H}_{0}$ atau dapat dikatakan bahwa tidak terdapat perbedaan yang signifikan antara kurva survival pasien yang merokok dengan kurva survival pasien yang tidak merokok.

\subsubsection{Pengujian Distribusi Data}

Pengujian distribusi data menggunakan uji Anderson Darling dengan waktu survival pasien Tuberkulosis Paru yang dihitung sejak pertama kali pasien masuk rumah sakit sampai dinyatakan sembuh. Hasil uji Anderson Darling dengan nilai uji statistik untuk distribusi Weibull dua parameter adalah 1,1808. Jika dibandingkan dengan nilai kritis pada taraf signifikansi $\alpha=0,05$ sebesar 2,5018, maka nilai uji Anderson Darling kurang dari nilai kritis tabel. Sehingga gagal tolak $\mathrm{H}_{0}$ atau dapat dikatakan bahwa data waktu survival pasien Tuberkulosis Paru sesuai dengan distribusi dugaan bahwa data berdistribusi Weibull dua parameter dengan $\lambda=7,4704$ dan $\gamma=2,1223$.

\subsection{Mendeteksi Multikolinearitas}

Cara mendeteksi adanya kasus multikolinearitas antar variabel bebas yakni dengan melihat nilai Variance Inflation Factor (VIF) dari variabel bebas umur yaitu 1,107. Nilai ini diperoleh dengan menggunakan software SAS. Nilai VIF dari variabel bebas umur kurang dari sepuluh yang artinya tidak terdapat adanya multikolinearitas pada data survival. Sedangkan pada variabel jenis kelamin, sesak nafas, batuk, demam, riwayat penyakit Tuberkulosis Paru, pekerjaan dan merokok saling bebas.

\subsection{Seleksi Model Terbaik}

Untuk mendapatkan model terbaik dalam Regresi Weibull, maka digunakan metode backward dan seleksi model terbaik yaitu dengan menggunakan kriteria Akaike's Information Criterion (AIC) yang dapat ditunjukkan pada Tabel 2.

Tabel 2. Nilai Akaike's Information Criterion (AIC)

\begin{tabular}{lc}
\hline \multicolumn{1}{c}{ Variabel } & AIC \\
\hline $\mathrm{X}_{1}, \mathrm{X}_{2}, \mathrm{X}_{3}, \mathrm{X}_{4}, \mathrm{X}_{5}, \mathrm{X}_{6}, \mathrm{X}_{7}, \mathrm{X}_{8}$ & 252,316 \\
$\mathrm{X}_{1}, \mathrm{X}_{2}, \mathrm{X}_{3}, \mathrm{X}_{4}, \mathrm{X}_{5}, \mathrm{X}_{6}, \mathrm{X}_{8}$ & 250,592 \\
$\mathrm{X}_{1}, \mathrm{X}_{3}, \mathrm{X}_{4}, \mathrm{X}_{5}, \mathrm{X}_{6}, \mathrm{X}_{8}$ & 250,492 \\
\hline
\end{tabular}

Berdasarkan Tabel 2, maka dapat diketahui bahwa nilai AIC terkecil sebesar 250,492 yang terdapat pada model dengan variabel independennya yaitu Umur, Sesak Nafas, Batuk, Demam, Riwayat Penyakit Tuberkulosis Paru dan Kebiasaan Merokok.

\subsection{Faktor-Faktor Yang Mempengaruhi Laju Kesembuhan Pasien Tuberkulosis Paru}

Untuk mengetahui faktor apa saja yang diduga dapat mempengaruhi laju kesembuhan pasien Tuberkulosis Paru maka digunakan pengujian secara serentak dan parsial. Hasil pengujian serentak mengunakan software SAS menunjukan nilai P sebesar 0,00031 yaitu kurang dari $\alpha(0,05)$, serta nilai $\ln \left(L\left(\omega^{\prime}\right)\right)=-117,2$ Dan $\ln (L(\hat{\Omega}))=-129,8$ sehingga diperoleh nilai $G_{\text {hitung }}^{2}$ sebagai berikut,

$$
G^{2}=-2 \ln \frac{L\left(\omega^{\prime}\right)}{L(\widehat{\Omega})}=25,21
$$


Maka didapatkan nilai $\chi_{6 ; 0,05}^{2}$ tabel sebesar 12,59. Sehingga keputusan yang diperoleh adalah tolak $\mathrm{H}_{0}$, karena nilai $G_{\text {hit }}^{2}$ lebih besar dibandingkan dengan $\chi_{6 ; 0,05}^{2}$ artinya minimal terdapat satu variabel independen yang signifikan terhadap model. Setelah dilakukan pengujian serentak didapat hasil bahwa terdapat minimal terdapat satu variabel independen yang signifikan terhadap model maka dilanjutkan ke pengujian parsial untuk mengetahui faktor-faktor apa saja yang signifikan terhadap model. Nilai estimasi parameter Regresi Weibull disajikan pada Tabel 3.

Tabel 3. Uji Signifikansi Parameter Secara Parsial

\begin{tabular}{ccccc}
\hline Variabel & Est. Parameter & Std. Error & $\mathrm{z}$ & P-value \\
\hline Intercept & 1,78935 & 0,193 & 10,2 & 0,0000 \\
\hline $\mathrm{X}_{1}$ & 0,00821 & 0,003 & 2,99 & 0,003 \\
$\mathrm{X}_{3}(2)$ & 0,43285 & 0,137 & 3,15 & 0,002 \\
$\mathrm{X}_{4}(2)$ & $-0,46616$ & 0,147 & $-3,16$ & 0,002 \\
$\mathrm{X}_{5}(2)$ & 0,35795 & 0,138 & 2,60 & 0,009 \\
$\mathrm{X}_{6}(2)$ & 0,35808 & 0,124 & 2,88 & 0,004 \\
$\mathrm{X}_{8}(2)$ & 0,43696 & 0,198 & $-2,20$ & 0,028 \\
\hline Scale $(\lambda)$ & 0,370 & & & \\
\hline Shape $(\gamma)$ & 2,7014 & & & \\
\hline
\end{tabular}

Pengujian parsial yang ditampilkan pada Tabel 3 menunjukkan nilai P masing-masing variabel bebas. Variabel umur, sesak nafas, batuk, demam, riwayat penyakit Tuberkulosis Paru dan merokok pada Tabel 2 memiliki nilai kurang dari $\alpha(0,05)$ sehingga kesimpulannya adalah tolak $\mathrm{H}_{0}$ yang artinya variabel-variabel tersebut berpengaruh secara signifikan terhadap model. Berikut adalah model Regresi Weibull.

$$
\begin{gathered}
\hat{\lambda}=\exp (1,78935+0,00821 X 1+0,43285 X 3-0,46616 X 4+0,35795 X 5+0,35808 X 6 \\
+0,43696 X 8)
\end{gathered}
$$

Nilai estimasi parameter shape $(\gamma)$ bernilai 2,7014 disubstitusikan pada fungsi hazard Regresi Weibull sebagai berikut,

$$
h\left(t_{i}\right)=\frac{\gamma}{\lambda^{\gamma}}=\frac{2,7014}{\lambda_{i}^{2,7014}} t_{i}^{2,704-1}
$$

\subsection{Hazard Ratio}

Selanjutnya, nilai Hazard Ratio pada penelitian ini disajikan pada Tabel 4.

Tabel 4. Nilai Hazard Ratio

\begin{tabular}{ccc}
\hline Variabel & Estimasi Parameter & Hazard Rasio \\
\hline Intercept & 1,78935 & 3,865 \\
\hline $\mathrm{X}_{1}$ & 0,00821 & 1,008 \\
$\mathrm{X}_{3}$ & 0,43285 & 1,542 \\
$\mathrm{X}_{4}$ & $-0,46616$ & 0,627 \\
$\mathrm{X}_{5}$ & 0,35795 & 1,430 \\
$\mathrm{X}_{6}$ & 0,35808 & 1,431 \\
$\mathrm{X}_{8}$ & 0,43696 & 1,548 \\
\hline
\end{tabular}

Berdasarkan Tabel 4 variabel umur memiliki nilai hazard ratio sebesar 1,008. Nilai ini bermakna bahwa setiap pertambahan satu satuan usia, maka kemungkinan untuk mencapai laju 
kesembuhan pada pasien adalah sebesar 1,008 kali. Variabel Sesak Nafas memiliki nilai hazard ratio sebesar 1,542. Nilai ini bermakna bahwa pasien yang tidak memiliki sesak nafas memiliki kemungkinan untuk mengalami laju kesembuhan sebesar 1,542 kali lebih besar daripada pasien memiliki sesak nafas.

Variabel Batuk memiliki nilai hazard ratio sebesar 0,627. Nilai ini bermakna bahwa pasien yang tidak memiliki batuk memiliki kemungkinan untuk mengalami laju kesembuhan sebesar 0,627 lebih besar daripada pasien memiliki batuk. Variabel Demam memiliki nilai hazard ratio sebesar 1,430. Nilai ini bermakna bahwa pasien yang tidak memiliki demam kemungkinan untuk mengalami laju kesembuhan sebesar 1,430 kali lebih besar dari pada pasien memiliki demam.

Variabel Riwayat Penyakit Tuberkulosis Paru memiliki nilai hazard ratio sebesar 1,431. Nilai ini bermakna bahwa pasien yang tidak memiliki riwayat penyakit Tuberkulosis Paru memiliki kemungkinan untuk mengalami laju kesembuhan sebesar 1,431 lebih besar daripada pasien memiliki riwayat penyakit Tuberkulosis Paru. Variabel Merokok memiliki nilai hazard ratio sebesar 1,548. Nilai ini bermakna bahwa pasien yang tidak merokok memiliki kemungkinan untuk mengalami laju kesembuhan sebesar 1,548 lebih besar daripada pasien memiliki kebiasaan merokok.

\section{Kesimpulan}

Peluang survival pasien Tuberkulosis Paru dengan kurva Kaplan Meier menginformasikan secara visual bahwa semakin lama pasien Tuberkulosis Paru mengalami kesembuhan $(t)$, maka probabilitas seorang pasien Tuberkulosis Paru untuk tidak sembuh hingga waktu $t$ semakin kecil. Waktu survival pasien Tuberkulosis Paru mengikuti distribusi Weibull berdasarkan uji Anderson Darling. Hasil Pengujian parsial pada uji log-rank menunjukkan bahwa variabel umur, sesak nafas, batuk, demam, riwayat penyakit tuberkulosis, dan merokok berpengaruh secara signifikan terhadap model. Selain itu, Laju Kesembuhan Pasien Tuberkulosis Paru dapat dilihat pada nilai hazard ratio di masing-masing variabel.

\section{Referensi}

[1] D. M. Purnamasari, "Tuberkulosis Masih Jadi Ancaman, Indonesia Negara dengan Beban TB Tertinggi Ketiga," KOMPAS.COM, 2021. [Online]. Available: https://nasional.kompas.com/read/2021/03/25/09171841/tuberkulosis-masih-jadi-ancamanindonesia-negara-dengan-beban-tb-tertinggi?page=all. [Accessed: 09-Jun-2021]

[2] A. Saidi, "Stigma Pengobat TBC Dan Mitos Terengi," Dinas Kesehatan Provinsi Gorontalo, 2021. [Online]. Available: https://dinkes.gorontaloprov.go.id/stigma-pengobat-tbc-dan-mitosterengi/. [Accessed: 15-Jun-2021]

[3] D. G. Kleinbaum and M. Klein, Survival Analysis. New York, NY: Springer New York, 2012.

[4] D. Collett, Modelling Survival Data in Medical Research, Third Edition. Bristol, UK: Chapman and Hall/CRC, 2015.

[5] P. D. Allison, Survival Analysis Using SAS:A Practical Guide. Cary, N.C.: SAS Institute, 1995.

[6] A. Solehah and M. Fatekurohman, "Analisis Ketahanan Hidup Pasien Kanker Paru Menggunakan Regresi Weibull," Indones. J. Appl. Stat., vol. 1, no. 2, pp. 79-87, 2019, doi: 10.13057/ijas.v1i2.25276.

[7] J. Yolanda and F. T. Kristanti, "Analisis Survival Pada Financial Distress Menggunakan Model Cox Hazard," BALANCE: Economic, Business, Management and Accounting Journal, vol. 17, no. 2, pp. 21-31, 2020.

[8] K. R. Pranita and F. T. Kristanti, "Analisis Financial Distress Menggunakan Analisis Survival." Nominal: Barometer Riset Akuntansi dan Manajemen, vol. 9, no. 2, pp. 62-79, 2020.

[9] B. Audina and M. Fatekurohman, "Analisis Survival pada Data Pasien Covid 19 di Kabupaten 
Jember," Berkala Sainstek, vol. 8, no. 4, pp. 118-121, 2020.

[10] S. Sulantari and W. Hariadi, "Analisis Survival Waktu Sembuh Pasien Covid-19 di Kabupaten Banyuwangi." Transformasi: Jurnal Pendidikan Matematika dan Matematika, vol. 4, no. 2, pp. 375-386, 2020.

[11] D. Lukitasari, A. Setiawan, and L. R. Sasangko, "Bayesian Survival Analysis untuk Mengestimasi Parameter Model Weibull-Regression pada Kasus Ketahanan Hidup Pasien Penderita Jantung Koroner," d'CARTESIAN, vol. 4, no. 1, pp. 26-33, 2015, doi: 10.35799/dc.4.1.2015.7531.

[12] A. R. Baghestani, S. S. Moghaddam, H. A. Majd, M. E. Akbari, N. Nafissi, and K. Gohari, "Survival analysis of patients with breast cancer using weibull parametric model," Asian Pacific J. Cancer Prev., vol. 16, no. 18, pp. 8567-8571, 2016, doi: 10.7314/APJCP.2015.16.18.8567.

[13] M. Kazempour-Dizaji, A. Kazemnejad, P. Tabarsi, and F. Zayeri, "Estimation of Ten-Year survival of patients with pulmonary tuberculosis based on the competing risks model in Iran," Tanaffos, vol. 15, no. 1, pp. 37-43, 2016.

[14] S. Daniel, K. E. Lasisi, and J. Banister, “Application of Survival Analysis of TB Patients Using Parametric Model: A Case Study of General Hospital Bayara," Asian J. Probab. Stat., vol. 6, no. 4, pp. 54-65, 2020, doi: 10.9734/ajpas/2020/v6i430169.

[15] S. S. Rajak, S. Ismail, and R. Resmawan, "Metode Conditional Autoregressive dalam Analisis Penyebaran Kasus Penyakit Tuberculosis," Jambura J. Probab. Stat., vol. 2, no. 1, pp. 28-34, Apr. 2021, doi: 10.34312/jjps.v2i1.9771. 